\title{
COVID-19 and Its Socio-Economic Impact on Selected Rural Areas of Katpadi Taluk in Vellore District of Tamil Nadu
}

\author{
G. Yoganandham ${ }^{1}$, Jayendira P. Sankar ${ }^{2 *}$ (1) R. Kalaichelvi ${ }^{3}$ \\ ${ }^{1}$ Economics, Thiruvalluvar University, Serkkadu, Vellore District, Tamil Nadu, India \\ ${ }^{2}$ College of Administrative and Financial Sciences, AMA International University, Salmabad, Kingdom of Bahrain \\ ${ }^{3}$ College of Computer Studies, AMA International University, Salmabad, Kingdom of Bahrain \\ Email: drgyoga@gmail.com, ^drpjai14@gmail.com,kalai_hasan@yahoo.com
}

How to cite this paper: Yoganandham, G., Sankar, J. P., \& Kalaichelvi, R. (2020). COVID-19 and Its Socio-Economic Impact on Selected Rural Areas of Katpadi Taluk in Vellore District of Tamil Nadu. Journal of Human Resource and Sustainability Studies, 8, 331-348.

https://doi.org/10.4236/jhrss.2020.84019

Received: October 16, 2020

Accepted: November 27, 2020

Published: December 1,2020

Copyright $\odot 2020$ by author(s) and Scientific Research Publishing Inc. This work is licensed under the Creative Commons Attribution International License (CC BY 4.0).

http://creativecommons.org/licenses/by/4.0/

\section{(c) (i) Open Access}

\begin{abstract}
The emergence of coronavirus at the end of 2019 has crossed the country's boundaries and spread the waves to the mobile and interdependent global population. The socio-economic impact of coronavirus in the middle and low-income countries mentioned the virus as SARS-CoV-2 has officially termed COVID-19. There is a need to identify the barriers and frame the strategies for socio-economic interventions in the COVID-19 pandemic. To manage the people infected with the COVID-19, there is a need for coordination between the health system and the general public. Also, there is a need for support from the financial system and welfare in people's quality of life. This pandemic situation is an alarming humanitarian crisis that seeks intensive care and support from public health. It is not possible only from the health sector and government, but also social workers, psychologists, experts in logistics, epidemiologists, and social scientists. Countries are implementing the lockdown and hygiene measures to cut the chain of spreading of the virus. Rapid transmission of COVID-19 in countries and the world needs a disease surveillance system, tracking, testing laboratories, and response treatment. In these circumstances, this research paper mainly concentrates on the COVID-19 and its impact on selected rural areas of Katpadi taluk in Vellore district of Tamil Nadu. It is a socially and timely relevant one and need of the hour.
\end{abstract}

\section{Keywords}

Global Population, Impact of COVID-19, Peak Stage of COVID-19, Public Health, Humanitarian Crisis, Epidemiologists, Psychologists, and Social Workers 


\section{Introduction}

The emergence of coronavirus at the end of 2019 has crossed the country's boundaries and spread the waves to the mobile and interdependent global population. The socio-economic impact of coronavirus in the middle and low-income countries mentioned the virus as SARS-CoV-2 has officially termed COVID-19 (Shretta, 2020). In India, there was a complete lockdown for eleven weeks and had built robust public health measures. The experts predicted the need for isolation wards, ICU beds, and ventilators might arise in mid-November. It was also estimated that the lockdown might be extended for another 34 days to 76 days to reduce the infection by 97 percent, and a sufficient time to prepare the health infrastructure. Currently, there is no medicine to cure or no vaccines to curb infection and restrict the pandemic. Countries insist on the daily routine changes like social distancing, hand hygiene, self-isolation for symptomatic people, work from home, educational institutions closure, and business closure (Park, 2020). There is a restriction for people's movement by closing the boundaries of the state and national levels. The intention is to restrict the spread of virus and time to prepare the health system.

The socio-economic fallout because of the pandemic is a threat to the nation's growth and global level. The virus has not come to an end, and already a slowdown of the world's economy. COVID-19 led to an economic slowdown and hit business areas like travel, tourism, aviation, and service sectors (Ghosh, 2020). Some businesses have come to an end. Significantly, the aviation industry faced a drastic fall in all airline routes (Singh, 2015). There are lost hours of 60 percent of the world population and 30 percent of joblessness (Chatterjee et al., 2020). The informal sector is the primary source of income and employment of several developing countries and some developing countries. Many households spend their handful of earnings on health and medical care (Sankar, 2018).

In Ranipet district, Thiruvalam and the adjoining areas of Katpadi taluk are in the process of opening their economies entirely, perhaps by the end of the month, despite recording some of their numbers of new cases in months. Ranipet districts, which have resisted the stay-home regulations for weeks, announced Saturday a record-high new coronavirus case, nearly 40 percent above its previous peak. The Ranipet district public health authorities severely ordered that people wear masks outdoors and generate massive protests at home and personal threats, without much evidence, to allow some businesses to remain open and force others to shut down. The reopening appeared to be managed in that same way, which struck some as arbitrary and beyond an otherwise liberal local government's authority.

As infection rates declined in the study area in early May, Public Health Officer began easing the stay-home rules and other districts that met specific state criteria. The district was antsy, with some local businesses shutting down for good. However, within weeks, the district's infection rates had nearly doubled, who had begun the job on March 10, decided that the county would 
not allow any more businesses to open, would prohibit the loosening of the rules on public gatherings, and would freeze other aspects of the next reopening phase. The pause would last at least 14 days, the high end of the virus incubation period. With this background, this paper mainly concentrates on COVID-19 and its impact on selected rural areas of Katpadi taluk in Vellore district of Tamil Nadu.

The people living in the adjoining areas of Katpadi taluk wear face masks in all indoor and outdoor public areas, placing him at odds with conservative regions such as the Ranipet district that have framed the masks infringement personal liberty. Tamil Nadu recorded two straight days of record-high new infections last weekend, and recently it sailed past the milestone of around 50 people killed by the virus. The state has recorded around 2000 total infections, and it is now reporting the highest weekly average of new cases, about 231 since the virus began.

Tamil Nadu sees infection rates bounce up and down. Doctors say increased testing only partially explains the jumps. Hospitals and ICUs have been filling up with new cases in many parts of the state. Infection rates in the Vellore district and along the southern border are also on the rise. In these circumstances, the study on COVID -19 and its impact on selected rural areas of Katpadi taluk in Vellore district of Tamil Nadu are essential and socially and timely relevant one and need of the hour.

The study's overall objective is to analyze the spread of COVID-19 in the adjoining areas of Katpadi taluk in Vellore District of Tamil Nadu from in analytical perspectives. The specific objectives are;

1) To study the nature and pattern of spreading of COVID-19 in selected rural areas of Katpadi taluk in Vellore district of Tamil Nadu.

2) To observe the knowledge, attitude, awareness, and survival of people living in the study area on COVID-19 pandemic.

3) To study the measures taken by the government to control the spreading of the COVID-19 pandemic in the study area, and

4) To suggest suitable policy measures to control the spreading of the COVID-19 pandemic in the study area.

Several factors determine the causes and consequences of spreading the COVID-19 pandemic in the Vellore District of Tamil Nadu in general and the study area. Based on these determining factors, few research questions are formulated for the research. They are,

1) What were the awareness levels in the villages of the study area regarding COVID-19?

2) How did the study area withstand various challenges posed by COVID-19?

\section{Review of Literature}

The literature review aims to find and review the essential conceptual and research papers on the COVID-19 pandemic and 1918 pandemic H1N1 virus to 
find the research gap and adopt the literature review findings in this study. The researcher attempted to review the studies carried out by various researchers on the COVID-19 pandemic and the 1918 pandemic H1N1 virus. Some of the studies reviewed were stated in chronological order in this chapter.

According to Harapan et al. (2020), it is not clear that the disease starts its spread from the Huanan seafood wholesale market. Still, in spreading the virus, bats do not need intermediaries in transmitting to humans always. Moreover, the present COVID-19 pandemic is a virus threat and public health problem for the whole world.

A determining contribution made by Kakodkar et al. (2020) elucidated that there is no doubt in declaring COVID-19 as a global pandemic. In the global pandemic, several evidence-based medicines were placed to measure the frequency of demonstrating the symptoms to create a stratification system of the risk factors involved in the COVID-19.

A study by Bang (2020) stated that the recent outbreak of COVID-19 is a global public health emergency. COVID-19 transmission through close person-to-person contact and droplets. There should be proper travel details, indentify the patients, physician awareness, restrict future spreading, history of patients, and compatible symptoms.

A considerable body of literature on Kläger (2020) investigated the need for a high prioritized health care system and proper handling of patients to manage the global crisis by COVID-19 pandemic. Further, to handle this crisis requires worldwide researchers to join their hands in finding the cure medicine and a vaccine. Moreover, global cooperation effort is the only mechanism to overcome this crisis.

A relevant study by Chatterjee et al. (2020) reviewed that in COVID-19, human beings get affected with the virus through the zoonotic transmission. COVID-19 is the virus that emerged as a third pandemic in the past two decades. The first virus was severe acute respiratory syndrome in 2003, and the second virus was middle-east respiratory syndrome coronavirus in 2012.

A detailed study revealed by Pathan et al. (2020) stated that during the emergency of 2019, COVID-19 started spreading worldwide. The government of India and the World Health Organization took several measures in the early identification of virus affected cases and to restrict the spread of the virus to the other parts of the country. However, in a short time, COVID-19 spread to the huge numbers and caused causalities.

A considerable body of literature on Small \& Beatty (2020) highlighted that the symptoms and signs of COVID-19 vary from person to person. There are some cases detected as asymptomatic (without any symptoms) frequency across populations. Health system outline created as per the World Health Organization; it is mandatory to assess the patients with a clinical illness to find out the COVID-19.

A study of MoFHW (2020) stated that all the necessary steps were taken by the Government of India to restrict the spread of the virus and manage the 
COVID-19 effectively. Moreover, the growing COVID-19 pandemic is very challenging not only for India but for the whole world. The challenges were not limited only to the health system; also to the socio-economic factors.

Several methods are reported in the literature addressed by Relief (2020) discussed that COVID-19 had created a stressful time for the whole world. All the countries started insisting on their citizens and residents to stay home to restrict the virus's spread. The preventive measures of the COVID-19 include social distancing, hand sanitizers, and face mask. Most business organizations started insisting their employees go to work at home; after the lockdown and curfew, half of their workplace employees on a rotation basis.

\section{Methodology of the Study}

The design of the study is descriptive and diagnostic study, based on both primary and secondary data. This study explores the impact of COVID-19 on the people living in the adjoining areas of Thiruvalluvar University in the Vellore district of Tamil Nadu with particular reference to knowledge, attitude, awareness, and survival in analytical perspectives. This study is a descriptive and diagnostic analysis based on primary and secondary sources of information and statistical data with high indexed journals, published data, and research discussed using the various definitions.

A qualitative approach was adopted for the study. The study utilized the krejcie and morgan sample size table for determining the sample size (Krejcie \& Morgan, 1970). Fifty sample respondent households of people living in the adjoining areas of Katpadi taluk in Vellore district of Tamil Nadu affected by the COVID-19 pandemic were interviewed with the help of a predetermined and well-structured interview schedule, and focus group discussions were conducted among people affected by the COVID-19 pandemic, community and religious leaders, and health providers and other key persons who were all purposively selected. Therefore the present study contemplates COVID-19 and its impact on people living in the selected rural areas of Katpadi taluk in Vellore district of Tamil Nadu. The data collected from the respondents with necessary COVID-19 precautionary protocol made the government (face mask, hand gloves, social distancing, and using hand sanitizers frequently).

Vellore District of Tamil Nadu is selected as the universe of the study. In this district, Katpadi taluk is selected for the study because Katpadi taluk in Vellore district of Tamil Nadu is high progress in the socio-economic development process compared to another taluk in this district (Sankar, 2016a). Therefore Katpadi taluk of Vellore district is the universe of the study. So based on the progress and growth of the socio-economic sector, Katpadi taluk in Vellore district is chosen for the study. However, a multi-stage random sampling technique was adopted to select the samples in the study area. In Katpadi taluk, six villages are selected for the study based on the population's percentage per the 2011 census. Serkkadu, Thenpalli, Thiruvalam, Perumalkuppam, Vallimalai, and Pe- 
riyamittur (Sankar \& Yoganandham, 2016). These six villages are the study area for this research work which are in the top revenue in the Katpadi taluk. Based on the study area's total population, 5 percent of the population was selected for the study (Varun, 2016).

This study aims to outline the causes, symptoms, and treatments related to the COVID-19 pandemic and how it can be diagnosed in patients and identified in human remains. The study also demonstrates how care for COVID-19 pandemic sufferers developed as the disease became more common and correctly identified. It analyses the social stigmas inflicted upon sufferers and the medical care and attention by religious institutions when other groups or organizations shunned those suffering from the COVID-19 pandemic. The rationale for this study is to identify trends surrounding the social stigmas attached to the COVID-19 pandemic and care from the first identifiable case of strain when the number of cases of COVID-19 pandemic appears to begin to decline.

Using archaeological evidence, historical records, and the published research of experts in the field, this study demonstrates that as the COVID-19 pandemic spread throughout the Vellore district of Tamil Nadu, religious organizations often took on the role of caregivers for COVID-19 pandemic sufferers through the ideal of religious. Therefore the study is a timely and socially relevant one and need of the hour.

\section{Data Analysis and Discussion}

\subsection{Profile of the Study Area}

Tamil Nadu is one of India's most developing states regarding socio-economic, cultural, historical, and political empowerment. Vellore district is one of the 38 districts in the Tamil Nadu state of India (Sankar, 2016b). Katpadi taluk is a taluk in the Vellore district of the Indian state of Tamil Nadu. According to the 2011 census, the taluk of Katpadi had 387,922, with 193,853 males and 194,069 females. There were 1001 women for every 1000 men of the ratio of male to female is almost 1:1. The taluk had a literacy rate of 74.58 . The child population in the age group below 6 was 18,402 Males and 17,728 Females.

\subsection{Analysis of the Respondents Data}

Age is one of the determining factors of socio-economic conditions. A family with several children and age-old people will highly suffer since their earning capacity is low. On the contrary, a family will be better off if it consists of more earning persons. The Demographic, Socio-Economic Profile of the Respondents is stated in Table 1.

Data shown in Table 1 reveals that the age-wise distribution of the respondents in the study area, 17 respondents belonged to the 25 - 45 years age group and 13 respondents belonged to bellow 25 years age group and ten respondents belonged 45 - 65 years age group, and the rest ten respondents belonged to above 65 years age group Monthly income-wise 25 respondents are earning up 
Table 1. Demographic, socio-economic profile of the respondents.

\begin{tabular}{|c|c|c|}
\hline Description & Frequency & Percent \\
\hline \multicolumn{3}{|c|}{ Age-wise distribution of the respondents } \\
\hline Bellow 25 & 13 & 26 \\
\hline $25-45$ & 17 & 34 \\
\hline $45-65$ & 10 & 20 \\
\hline Above 65 & 10 & 20 \\
\hline \multicolumn{3}{|l|}{ Education Status } \\
\hline Higher secondary & 23 & 46 \\
\hline Graduate & 27 & 54 \\
\hline \multicolumn{3}{|l|}{ Monthly Income (in Rs.) } \\
\hline Up to 20,000 & 25 & 50 \\
\hline 20,000 - Rs. 30,000 & 16 & 32 \\
\hline Rs. 30,000 - 40,000 & 9 & 18 \\
\hline \multicolumn{3}{|l|}{ Occupation Status } \\
\hline Service & 22 & 44 \\
\hline Business & 13 & 26 \\
\hline Professional & 15 & 30 \\
\hline \multicolumn{3}{|l|}{ Marital Status } \\
\hline Married & 24 & 48 \\
\hline UnMarried & 26 & 52 \\
\hline \multicolumn{3}{|l|}{ Housing Status } \\
\hline Pucca Houses & 09 & 18 \\
\hline Semi - Pucca Houses & 15 & 30 \\
\hline Katcha Houses & 20 & 40 \\
\hline Others & 06 & 12 \\
\hline
\end{tabular}

Source: Computed from primary data.

to Rs.20,000 and 16 respondents are earning Rs.20,000 - 30,000, and the rest of 9 respondents earn to Rs.30,000 - 40,000.

Based on the marital status, the household has been divided into three categories: married, unmarried, and others. Marital status is one of the critical factors that influence the employment and income of households. It can be observed from Table 1, The Marital status wise, 24 respondents are married, and 26 respondents were unmarried.

Education is a basic necessity for social awareness. Education brings shapes out a better society, but lack of education prevents social enchantment and quality of learning (Elumalai et al., 2020). People give very little importance to education due to a lack of proper guidance, knowledge, awareness, and finance. Most of them are not yet conscious of the benefits of education and consequent 
economic gains. The issues related to education, and economic development, including the financing of education and demand for education, play a crucial role in empowering weaker sections of the society in general and people. People's literacy rate in the Vellore District is significantly less than another leading district of Tamil Nadu.

Moreover, on the other hand, 7.50 percent of the respondents have completed others category of education, which includes polytechnics/diplomas, Certificate courses, ITI, and other job oriented short term computer courses, and the remaining 7.50 percent of them were qualified postgraduate and above, respectively. It can be noted from Table 1, education-wise, 27 graduate people, and 23 people were higher secondary passed.

The area-wise housing conditions of the respondents are given in Table 1. It reveals that the details of the respondents' type of house; those are four categories of housing facilities in the study area, namely Katcha Houses, Semi-Pucca Houses, Pucca Houses, and others it includes thatched roof house, tiled roof house, concrete roof houses. Among 50 respondents, only 40 percent live in the Katcha houses, whereas 30 percent of the respondents stay in the Semi-Pucca houses, 18 percent live with pucca houses, and the remaining 12 percent live in the other categories houses.

They were attached to the households as part of the family (Sankar et al., 2020). Today, most of them work in agriculture or related activities as daily wage earners. The study's primary occupation is working as household activities and laborer in agriculture and its related activities, informal sector laborers, and other traditional works. Most of them work as agricultural laborers, tree cutters, and informal sector laborers daily in the study area. Their works are not regular and stable income, but it is uncertainty and seasonal one. Their economic status reveals that the majority of them are living in economic backwardness with poverty and inequalities. It can be observed from Table 1, the occupation wise 22 respondents related to the service sector, and 15 respondents are professional, and the rest of 13 respondents related to the business sector.

Data are shown in Table 2 depicted that details of COVID-19 symptoms experienced in the last 15 days. Fever symptoms reported respondents are 25 percent, while cough symptom reported persons are 62 percent. Among the symptoms, cough is ranked first. Whereas skin rash, muscle or body aches, and shortness of breath constitute 48 percent, 46 percent, and 38 percent, respectively. It is shocking to note that 62 percent of the respondents are affected by cough and its related symptoms.

The field survey shows that all households have a ration card, and they are receiving essential items from the ration shop. People have treated the ration card as assets, and they are pledging this card then and then to get a loan from money lenders and landlords. The details of Symptoms experienced in the last 15 days by the respondents in the study area are given in Table 2 .

People suffer from stomach aches, fever, cough, body pain, skin rash, and headache. They are using more without a properly balanced diet without getting 
Table 2. Symptoms experienced in the last 15 days.

\begin{tabular}{|c|c|}
\hline Types of Disease & Percentage of peoples affected \\
\hline Fever & 25 \\
\hline Chills & 10 \\
\hline Runny or stuffy nose & 30 \\
\hline Chest congestion & 15 \\
\hline Skin rash & 48 \\
\hline Cough & 62 \\
\hline Sore throat & 13 \\
\hline Sneezing & 28 \\
\hline Muscle or body aches & 46 \\
\hline Headaches & 29 \\
\hline Fatigue or tiredness & 19 \\
\hline Shortness of breath & 38 \\
\hline Abdominal discomfort & 27 \\
\hline Nausea o vomiting & 34 \\
\hline Diarrhea & 32 \\
\hline Changed or lost sense of taste or smell & 15 \\
\hline Loss of appetite & 12 \\
\hline
\end{tabular}

Source: Computed from primary data.

proper treatment and advice from the reputed doctors. This will cause stomach aches. During a discussion with the respondents in the study area, out of 50 respondents, 43.33 percent of the respondent households suffer from simple diseases that happen seasonally and occasionally. 14.17 percent of the respondent households are affected heavily by diseases; 32.50 percent of the respondent households in the study area is mentioned that they are not affected by any type of disease. The remaining 10 percent of the respondent households belong to the no response category.

During a discussion with the respondents, out of the 50 respondent households, 33.33 percent of them are not having any knowledge of the health insurance schemes offered by the government and other private institutions, 55.00 percent of the respondent households in the study area are having proper knowledge on the health insurance schemes provided by both central and state governments. Moreover, the remaining 11.67 percent of the respondent households are not answering for this. It is shocking to note that from the preceding analysis, it can be concluded that none of them is regularly and adequately followed any kind of insurance schemes offered by various institutions. This reveals that most of the respondents have awareness and knowledge about the health insurance schemes available in the study area.

The evidence stated in Table 3 reveals that Measures taken by the respondents 
Table 3. Measures taken by the respondents to face coronavirus.

\begin{tabular}{lc}
\hline \multicolumn{1}{c}{ Details of Measures taken } & Percentage \\
\hline Canceled a doctor appointment & 17 \\
Worn a face mask & 34 \\
Visited a doctor or hospital & 52 \\
Canceled or postponed work activities & 47 \\
Canceled of postponed school activities & 69 \\
Canceled or postponed dentist or another appointment & 24 \\
Canceled outside housekeepers or caregivers & 56 \\
Avoided some or all restaurants & 22 \\
Worked from home & 89 \\
STUDIED AT HOME & 86 \\
Canceled or postponed pleasure, social, or recreational activities & 78 \\
Stockpiled food or water & 32 \\
Avoided public or crowded places & 80 \\
Prayed & 84 \\
Avoided contact with high-risk people & 75 \\
Washed or sanitized hands & 90 \\
Kept six feet distance from that outside from my household to your household & 67 \\
Stayed home because I felt unwell/you felt unwell & 69 \\
\hline
\end{tabular}

Source: Computed from primary data.

to face coronavirus in the study area. Out of the total of 50 respondents, 90 percent of them washed or sanitized hands as protective measures from COVID-19. At the same time, 89 percent of them worked from home as protective measures. Simultaneously, only 17 percent of them have canceled a doctor's appointment relating to COVID-19. It is interesting to note that 84 percent of the respondents pray to god to safeguard from Coronavirus (NORC, 2020).

The information provided in Table 4 observed that testing options and tracking people who may have COVID-19 help slow the spread of this virus. The overwhelming majority ( 85 percent) of the respondents Installing an app on your phone that asks you questions about your symptoms and provides recommendations about COVID-19. Whereas, 78 percent of the respondents in the study area stated that installing an app on your phone tracks your location and sends push notifications if you might have been exposed to COVID-19.

The statistical information given in Table 5 depicted that the details of personal plans changed/affected by the type of COVID-19 restrictions in the study area. One hundred percent restrictions are practiced by K-12 school closure, Pre-K or child care closure, College or training closure, and International travel restrictions or bans. At the same time, 98 percent of the respondents stated that work closure is a significant study area restriction. 
Table 4. Options for testing and tracking people who may have COVID-19 in order to help slow the spread of this virus.

\begin{tabular}{lcc}
\hline \multicolumn{1}{c}{ Particulars } & Option & Percentage \\
\hline $\begin{array}{l}\text { Installing an app on your phone that asks you questions about your } \\
\text { symptoms and provides recommendations about COVID-19 }\end{array}$ & Extremely likely & 85 \\
$\begin{array}{l}\text { Installing an app on your phone that tracks your location and sends } \\
\text { push notifications if you might have been exposed to COVID-19 }\end{array}$ & Very likely & 78 \\
$\begin{array}{l}\text { Using a website to log your symptoms and location and get } \\
\text { recommendations about COVID-19 }\end{array}$ & Moderately likely \\
$\begin{array}{l}\text { Testing you for COVID-19 infections using a q-tip to swab your } \\
\text { cheek or nose }\end{array}$ & Not too likely \\
$\begin{array}{l}\text { Testing you for immunity or resistance to COVID-19 by drawing a } \\
\text { small amount of blood }\end{array}$ & Not likely at all \\
\hline
\end{tabular}

Source: Computed from primary data.

Table 5. Details of personal plans changed/affected by the type of COVID-19 restrictions.

\begin{tabular}{|c|c|}
\hline Types of Restrictions & Percentage \\
\hline K-12 school closure & 100 \\
\hline Pre-K or child care closure & 100 \\
\hline College or training closure & 100 \\
\hline Ban on gatherings or 250 people or more & 96 \\
\hline Ban on gatherings of 50 people or more & 72 \\
\hline Ban on gatherings of 10 people or more & 34 \\
\hline Closure of place of worship & 86 \\
\hline Reduced public transportation & 94 \\
\hline Other reduced public services & 59 \\
\hline Closure of bars & 56 \\
\hline Closure of restaurants & 93 \\
\hline Closure of gyms or fitness facilities & 95 \\
\hline Closure of other business & 90 \\
\hline Canceled sport events & 92 \\
\hline Closure of work & 98 \\
\hline Work from home requirements & 96 \\
\hline Quarantine requirements or stay-at-home orders & 98 \\
\hline International travel restrictions or bans & 100 \\
\hline Domestic travel restrictions or bans & 99 \\
\hline
\end{tabular}

Source: Computed from primary data.

Coronaviruses are a large family of viruses that may cause illness in animals or humans. In humans, several coronaviruses are known to cause respiratory infections ranging from the common cold to more severe diseases such as Middle East Respiratory Syndrome (MERS) and Severe Acute Respiratory Syndrome 
(SARS). The most recently discovered Coronavirus causes coronavirus disease COVID-19. Data presented in Table 6 stated that the details of unexpected expenditure incurring due to COVID-19 in the study area. Out of the total of 50 sample respondents in the study area, 95 percent of them were stated that Put it on my/your credit card and pay it off in full at the next statement as the covering of unexpected expenses. At the same time, 80 percent of them stated that Putting it on my/your credit card and paying it off over time is the primary plan for covering the unexpected expenses relating to COVID-19 (Abrar-ul-Haq et al., 2020).

The statistical details provided in Table 7 explain the details of the main reason for not working for pay in the study area. Out of 50 sample respondents in the study area, 86 percent of the respondents mentioned that they were unemployed and looking for work starting after March 1, 2020, when COVID-19 began spreading in the study area. While 82 percent of them stated that retirement is the main reason for not working for pay, 54 percent of them stated that they were not at my regular jobs because caring for someone with COVID-19 is the leading cause of not working to pay the study area.

Table 6. Details of incurring unexpected expenses.

\begin{tabular}{lc}
\hline \multicolumn{1}{c}{ Covering of unexpected expenses } & Percentage \\
\hline Put it on my/your credit card and pay it off in full at the next statement & 95 \\
Put it on my/your credit card and pay it off over time & 80 \\
Use money currently in my/your checking or savings account or with cash & 72 \\
Use money from a bank loan or line of credit & 49 \\
Borrow from a friend or family member & 62 \\
Use a payday loan, deposit advance, or overdraft & 28 \\
Sell something & 37 \\
I/you would not be able to pay for it right now & 62 \\
\hline
\end{tabular}

Source: Computed from primary data.

Table 7. Details of the main reason for not working for pay.

\begin{tabular}{lc}
\hline \multicolumn{1}{c}{ The main reason for not working for pay } & Percentage \\
\hline I do not want to be employed at this time & 37 \\
I am retired & 82 \\
I was laid-off temporarily or furloughed & 31 \\
I was not at my usual jobs because I was caring for children, not in school & 51 \\
I was not at my usual jobs because I was caring for an elderly person & 54 \\
I was not at my usual jobs because I was caring for someone with COVID-19 & 39 \\
I was not at my usual jobs because I was recovering from COVID-19 or isolating due \\
to exposure to COVID-19
\end{tabular}

Source: Computed from primary data. 
Data showed that Table 8 depicted the details of forms of income/assistance received/applied for the last 15 days. Out of the 50 total sample respondents in the study area, 78 percent stated that did not receive nor apply for any kind of social security measures to face COVID-19 consequences in the study area, followed by 76 percent of them mentioned that they are tried to apply for supplemental nutrition assistance program or food stamps. The information provided in Table 9 clearly stated that the details of health insurance/health coverage plans in the study area. Out of the total of 50 sample respondents, the overwhelming majority (72 percent) stated that they are not insurance purchased directly from an insurance company by you or another family member. Followed by 46 percent mentioned that they are obtained insurance through a current or former employer or union of yours or another family member.

Table 8. Details of forms of income/assistance received/applied since last 15 days.

\begin{tabular}{lcc}
\hline \multicolumn{1}{c}{ Forms of Income/Assistance } & Options & Percentage \\
\hline Unemployment Insurance/benefits & Received & 33 \\
Supplemental Nutrition Assistance Program or Food Stamps & Tried to apply for & 76 \\
Temporary Assistance for Needy Families. & Applied for & 48 \\
Social Security & Did not receive nor & 78 \\
Supplemental Social Security & apply for any & 32 \\
Any kind of government health insurance or health coverage & Tried to apply for \\
plan, including Medicaid. Medical Assistance or Medicare & Applied for \\
Other aid from the government & Received \\
Assistance from a union or other association & Applied for \\
Assistance from a church or religious organization & Applied for & 22 \\
Assistance from another community organization & Tried to apply for \\
Other assistance & Tried to apply for & 31 \\
\hline
\end{tabular}

Source: Computed from primary data.

Table 9. Details of health insurance/health coverage plans.

\begin{tabular}{lcc}
\hline \multicolumn{1}{c}{ Health insurance/Health coverage plans } & Options & Percentage \\
\hline $\begin{array}{l}\text { Insurance through a current or former employer or union of yours or } \\
\text { another family member }\end{array}$ & Yes & 46 \\
$\begin{array}{l}\text { The insurance purchased directly from an insurance company by you } \\
\text { or another family member }\end{array}$ & No & 72 \\
$\begin{array}{l}\text { Military health care } \\
\begin{array}{l}\text { Medicaid, Medical Assistance, or any kind of government-assistance } \\
\text { plan for those with low incomes or a disability }\end{array}\end{array}$ & Yes \\
$\begin{array}{l}\text { Medicare for people } 65 \text { and older or people with specific disabilities } \\
\text { Other health insurance or health coverage plans }\end{array}$ & Yes & 38 \\
\hline
\end{tabular}

Source: Computed from primary data. 
The most common symptoms of COVID-19 are fever, dry cough, and tiredness. Other symptoms that are less common and may affect some patients include aches and pains, nasal congestion, headache, conjunctivitis, sore throat, diarrhea, loss of taste or smell, or a rash on skin discoloration of fingers or toes.

The statistical evidence provided in Table 10 depicted the details of a doctor or other health care provider's statement relating to COVID-19 and its related symptoms in the study area. Out of the total of 50 sample respondents in the study area, 90 percent of the respondents stated that Diabetes fluctuations are the main factor prevailing in the study area, followed by high blood pressure or hypertension symptoms are there among the respondents (82 percent). Simultaneously, only 21 percent of them stated that liver disease or end-stage liver disease symptoms affected them (Bergo, 2020).

Data provided in Table 11 stated that persons currently live in households at least 50 percent of the time. Out of the total of 50 sample respondents $n$ the study

Table 10. Details of doctor or other health care provider statement.

\begin{tabular}{lcc}
\hline Doctor or other health care provider statement & Options & Percentage \\
\hline Diabetes & Yes & 90 \\
High blood pressure or hypertension & Yes & 57 \\
Heart disease, heart attack, or stroke & Yes & 65 \\
Asthma & No & 40 \\
Chronic lung disease and COPD & Not Sure & 28 \\
Bronchitis and emphysema & Not Sure & 49 \\
Allergies & No & 37 \\
A mental health condition & Not Sure & 21 \\
Cystic fibrosis & No & 35 \\
Liver disease or end-stage liver disease & Not Sure & 29 \\
Cancer & No & 34 \\
A compromised immune system & Not Sure & No \\
Overweight or obesity & & 42 \\
\hline
\end{tabular}

Source: Computed from primary data.

Table 11. Persons currently live in household at least 50 percent of the time.

\begin{tabular}{cc}
\hline Persons currently live in the household at least 50 percent of the time & Percentage \\
One person live by myself & 92 \\
Two persons & 96 \\
Three persons & 78 \\
Four persons & 64 \\
Five persons & 57 \\
Six or more persons & 56
\end{tabular}

Source: Computed from primary data. 
area, 94 percent of them stated that their family size is two persons. They severely followed the restrictions and procedures implemented by the government relating to COVID-19. Followed by 92 percent of them stated that they are single-member families; they also follow the rules and regulations severely implemented by the governments relating to the COVID-19 pandemic (Kim \& Laurence, 2020).

\section{Conclusion and Suggestions}

Based on the study, there is a need for socio-economic interventions and strategies to overcome the barriers of COVID-19. Coordination between the health system, financial system, and general public plays a crucial role in handling the COVID-19 pandemic effectively and to ensure the quality of life. During this pandemic, community-centered care is more appropriate than patient-centered care. Further, the COVID-19 pandemic solution is needed for the hospitals and the entire population. Pandemics are uncertain, so there is a need for long-term health care and hospital management plans for the next pandemic. Hospitals are filled with a high containment of 300 beds out of 900 beds for COVID-19 patients. Also, for a reasonable chance of survival, 70 percent of ICU beds were reserved for critically ill COVID-19 patients.

The current situation forces the health care sector to work below the usual standards. For instance, ICU bed wait times are around an hour-long; old-age patients will not get the usual treatment; sometimes die alone without proper care. The western health care system is always center around patient-centered care, however, during the pandemic, better to opt the community-centered care for better crisis management. Also, there are some of the worst situations like overcrowded hospitals, non-availability of collapsed medications, protective equipment, oxygen, and ventilators. Further, the health care system is struggling to provide regular facilities like pregnancy and child care. Simultaneously, an increase in death and concern related to the cemeteries increase the problems in health care.

The situation is not fruitful because of a lack of expertise in handling the epidemic environment. Further, a proper mechanism is needed for the hospitals and the general public to handle the situation effectively. Front-line warriors, especially health workers, become carriers, and sick will get a high level of stress. To overcome the critical situation, it is needed to appoint many front line workers for the hospitals and the general public. Like mobile clinics and home care, some other sources will avoid unnecessary movement and reduce hospitals' overcrowding. It will also reduce patients' hospitalization, disease severity, protect health care workers, and minimize protective equipment (ICU wards and ventilators).

The current pandemic situation has increased the fear of recession and collapse of the financial condition of the country. There should be a welfare leadership connected with a strong business and government for the broader society. Moreover, the implementation of immediate financial relief measures is 
needed to handle the fall down. Policymakers and governments need to develop medium and long-term planning to re-energize and re-balance the economy to handle the crisis. Further, a comprehensive socio-economic development plan with a sustainable and robust business model to encourage entrepreneurs. It is also mandatory that financial institutions and governments re-evaluate and re-assess continuously to ensure the economy's standard and stable conditions.

\section{Need for Long-Term Plan for the Next Pandemic}

This pandemic situation is an alarming humanitarian crisis that seeks intensive care and support from public health. It is not possible only from the health sector and government, but also social workers, psychologists, experts in logistics, epidemiologists, and social scientists. Countries are implementing the lockdown and hygiene measures to cut the chain of spreading of the virus. The severity of the COVID-19 pandemic has been insisted several times by the World Health Organization in preventing and restricting disease. Some of the brave decisions like curfew and complete lockdown will slow down the spread of COVID-19.

Complete lockdown is of great importance; in reducing infection, social distancing plays a vital role. Moreover, complete lockdown and curfew are not possible and advisable for the long term period; it will create serious economic problems, but relaxing the preventive measures may increase the virus's spread. Pandemics are uncertain, so it is a need of an hour to have long-term health care, hospital management plans, financial institutions, and governments for the next pandemic. Further, global effort is needed to handle and counter the COVID-19. This virus is not specific; it spread very fast, and it is more contagious all over the world. Also, the virus will spread rapidly because of centralized society activity. These are essential glimpses, and preventive measures need to consider in handling future pandemics.

\section{Limitations and Future Directions}

The study was well organized with framed objectives, literature, reliability, validity, analysis, and conclusion. Nevertheless, still, some of the limitations may be addressed in future research. These limitations may help the researchers in framing their researches. The study area is a small one; therefore, any conclusions and inferences drawn from the study are not universally acceptable. This study's core aspect is purely based on primary data; this includes many inconveniences like lack of cooperation from the respondents, lack of field survey facilities, and lack of cooperation from the officials.

\section{Conflicts of Interest}

The authors declare no conflicts of interest regarding the publication of this paper.

\section{References}

Abrar-ul-Haq, M., Asad, M., Natarajan, V., Sankar, J. P., \& Asif, M. U. (2020). Microfin- 
ance and Empowerment: A Case Study on Beneficiaries of a Community Development Program. Hamdard Islamicus, 43, 378-388.

Bang, K. M. (2020). Coronavirus Disease 2019 and Pandemic in the World: A Literature Review. EC Pulmonology and Respiratory Medicine, SI, 35-43.

Bergo, I. (2020). The Second Wave Threat. Green Left Website. https://www.greenleft.org.au/content/blog-covid-19-crisis-europe

Chatterjee, P., Nagi, N., Agarwal, A., Das, B., Banerjee, S., Sarkar, S. et al. (2020). The 2019 Novel Coronavirus Disease (COVID-19) Pandemic: A Review of the Current Evidence. Indian Journal of Medical Research, 151, 147-159.

https://doi.org/10.4103/ijmr.IJMR 51920

Elumalai, K. V., Sankar, J. P., Kalaichelvi R., John, J. A., Menon, N., Alqahtani, M. S. M., \& Abumelha, M. A. (2020). Factors Affecting the Quality of E-Learning during the COVID-19 Pandemic from the Perspective of Higher Education Students. Journal of Information Technology Education: Research, 19, 731-753. https://doi.org/10.28945/4628

Ghosh, S. (2020). Predictive Model with Analysis of the Initial Spread of COVID-19 in India. International Journal of Medical Informatics, 143, Article ID: 104262. https://doi.org/10.1016/j.ijmedinf.2020.104262

Harapan, H., Itoh, N., Yufika, A., Winardi, W., Keam, S., Te, H. et al. (2020). Coronavirus Disease 2019 (COVID-19): A Literature Review. Journal of Infection and Public Health, 13, 667-673. https://doi.org/10.1016/j.jiph.2020.03.019

Kakodkar, P., Kaka, N., \& Baig, M. (2020). A Comprehensive Literature Review on the Clinical Presentation, and Management of the Pandemic Coronavirus Disease 2019 (COVID-19). Cureus, 12, e7560. https://doi.org/10.7759/cureus.7560

Kim, H. H.-S., \& Laurence, J. (2020). COVID-19 Restrictions and Mental Distress among American Adults: Evidence from Corona Impact Survey (W1 and W2). Journal of Public Health, fdaa148. https://doi.org/10.1093/pubmed/fdaa148

Kläger, S. (2020). COVID-19 Taskforce. European Clinical Research Infrastructure Network Website. https://ecrin.org/covid-19-taskforce

MoFHW (2020). Growing Pandemic of COVID-19-Challenges and Issues. https://www.mohfw.gov.in/

NORC (2020). COVID Impact Survey: Week3, National Findings. https://apnorc.org/wp-content/uploads/2020/06/covid w3 topline national.pdf

Park, A. (2020). Wearing Face Masks and Social Distancing Actually Work to Contain COVID-19, According to a New Study. Time Health Website. https://time.com/5846288/social-distancing-f/

Pathan, M. M., Umar, N., Vijay, N., Patel, S. I., \& Pathan, H. M. (2020). Recrudescence of COVID-19: A Review of Literature and Indian Perspective. IP International Journal of Medical Microbiology and Tropical Diseases, 6, 1-5. https://doi.org/10.18231/j.ijmmtd.2020.001

Relief, E. (2020). COVID-19 Support for the US. https://reliefweb.int/organization/ird

Sankar, J. P. (2016a). Problems and Constraints Faced by Milk Producers and Milk Co-Operative Societies in Tamil Nadu with Special Reference to Vellore District. Research Directions, 3, 1-10.

Sankar, J. P. (2016b). Various Channels of Milk Marketing in Tamil Nadu with Special Reference to Vellore District. Indian Streams Research Journal, 6, 1-8.

Sankar, J. P. (2018). Impact of Quality of Work Life on Job Satisfaction: A Case Study on Staff Nurses of Thiruvallur District of Tamil Nadu. International Journal of Innovative 
Research in Management Studies, 3, 1-7.

Sankar, J. P., \& Yoganandham, G. (2016). Milk Co-Operatives in Tamil Nadu-An Impact Assessment (1st ed., North Carolina, Ed.). Solapur: Lulu Publication.

Sankar, J. P., Yoganandham, G., \& John, J. A. (2020). Work-Family Balance in Textile Industries of Tamil Nadu. International Journal of Psychosocial Rehabilitation, 24, 12522-12537.

Shretta, R. (2020). The Economic Impact of COVID-19. University of Oxford Website. https://www.research.ox.ac.uk/Article/2020-04-07-the-economic-impact-of-covid-19

Singh, R. (2015). Empirical Examination of the Impact of Total Quality Services on Hospitality Industry Business. Journal of Quality Assurance in Hospitality and Tourism, 16, 389-413. https://doi.org/10.1080/1528008X.2015.1013411

Small, C. N., \& Beatty, N. L. (2020). Atypical Features of COVID-19: A Literature Review. Journal of Clinical Outcomes Management, 27, 131-134. https://doi.org/10.12788/jcom.0005

Varun, K. M. (2016). E-Agriculture and Rural Development. Journal of Chemical and Pharmaceutical Sciences, 9, 3356-3362. 